International Journal of Instruction e-ISSN: 1308-1470 • www.e-iji.net

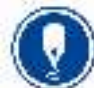

July $2021 \bullet$ Vol.14, No.3

p-ISSN: 1694-609X

pp. 187-206

Article submission code

20200416115839

Received: 16/04/2020

Revision: 05/12/2020

Accepted: 28/12/2020

OnlineFirst: 24/04/2021

\title{
The Effect Size of Different Learning on Critical and Creative Thinking Skills of Biology Students
}

\section{Supratman}

Postgraduate Student at Universitas Negeri Malang; and Biology Education Department Universitas Samawa, Indonesia, supratman@universitas-samawa.ac.id

Siti Zubaidah

Prof., Biology Department, Universitas Negeri Malang, Indonesia, siti.zubaidah.fmipa@um.ac.id

\section{Aloysius Duran Corebima}

Prof., Universitas Kanjuruhan, Malang, Indonesia, durancorebima@gmail.com

\section{Ibrohim}

Dr., Biology Department, Universitas Negeri Malang, Indonesia,

ibrohim.fmipa@um.ac.id

This quasi-experimental research aimed at investigating the effect of ProblemOriented Project-Based Learning (POPBL), Student Team Achievement Division (STAD), POPBLSTAD integration, and conventional learning on students' critical and creative thinking skills. Essay tests conducted to 129 students. The results of the test assessed using a relevant rubric. Posthoc analyses, namely LSD and effect size analyses, were used to analyze the data. The results of the ANCOVA analysis show that the learning model had a significant effect on students' critical thinking skills as well as on their creative thinking skills. The LSD analysis result showed that POPBLSTAD integration achieved a higher score of critical thinking compared to STAD, POPBL, and conventional learning $(21.22 \%, 16.11 \%$, and $39.38 \%$, respectively). Likewise, related to creative thinking, the POPBLSTAD integration score was $25.91 \%, 18.57 \%$, and $53.29 \%$ higher than those of STAD, POPBL, and conventional learning, respectively. Besides, all effect size analyses showed that POPBLSTAD obtained a higher effect-size score in critical thinking (high criteria) compared to STAD, POPBL, and conventional learning $(0.68,0.65$, and 0.82 , respectively). Similarly, the POPBLSTAD integration achieved a higher effect-size score of creative thinking (high criteria) compared to STAD, POPBL, and conventional learning $(0.66,0.55$, and 0.83 , respectively). Both analyses have demonstrated similar interpretations; thus, the two types of analyses should simultaneously be used to obtain complete research information.

Keywords: creative thinking, critical thinking, effect size, learning models, skills

Citation: Supratman., Zubaidah, S., Corebima, A. D., \& Ibrohim. (2021). The Effect Size of Different Learning on Critical and Creative Thinking Skills of Biology Students. International Journal of Instruction, 14(3), 187-206. https://doi.org/10.29333/iji.2021.14311a 


\section{INTRODUCTION}

The statistical significance analysis in quantitative research related to correlational research or experimental research (the effectiveness) is an absolute necessity. However, this is not sufficient if the results of the effect size testing not reported. The fact shows that the results of quantitative research have focused on describing the correlation and the differences between variables (Maher, Markey, \& Erbet-May, 2013). Most researchers rely heavily on the results of statistical significance analysis to determine whether or not the effect observed is significant. On the other hand, the strength of the correlation and the differences between each variable rarely considered (Osbourne, 2008; Kotrlik Williams \& Jabor, 2011). Statistical significance test sometimes does not provide complete information about the magnitude of the effects, correlations, and differences between each variable studied (Nakagawa \& Cuthill, 2007; Ferguson, 2009). As a result, when a meta-analysis carried out, the effect size of the research results in various disciplines shows a small value of effect size (Mazen, Hemmasi, \& lewis 1987; Ellis, 2010).

Much educational research shows that the results of a statistical significance test often encounter some problems. Because the numerical presentation of the test results presented mainly, while some other important issues, such as the effect size, are often ignored (Fan, 2001; Kortlik \& William, 2003; Morris \& Frit, 2013). As a result, most researchers only rely on the results of the statistical significance test. May imply the limitations of the understanding and application of findings of educational research practices (Maher et al., 2013). Also, the interpretation of statistical testing tends to have potentially incomplete information (Lakens, 2014). Therefore, the statistical significance test and effect size test viewed from the differences between variables opens up opportunities to conduct further research.

The effect size analysis in experimental research has an important role in providing complete information on the interpretation of statistical analysis results. Maher, Markey, \& Erbet-May (2013) explained that the effect of size testing in quantitative-based educational research was significant in providing an evaluation of research findings. Because the effect size is a simple way to measure differences between the two groups, which has many advantages compared to the statistical significance test (Coe, 2002; Balow, 2017). Effect size analysis aims at providing information about the size of the scale that reflects the practical significance of the differences or the correlation between variables (Hojat \& Xu, 2004) focusing on the meaning of results to assess the functional relevance of the results of quantitative research (Kotrlik et al., 2011). According to Fan (2001), the effect size and statistical significance are analyses that complement each other, and both should considered when evaluating quantitative research.

Another research measuring the effect size by using two categories, namely comparing two or more groups and determining the strength of the correlation between variables using Cohen's analysis (1988) is such as the research by Abraham et al. (2012) which analyzes how learning treatment on the students' perception posttest scores on the evolution learning material. Also, the research by Matthews, Adams, \& Goos (2010) examined the differences in students' beliefs about the role of mathematics in biological 
sciences. Gottesman \& Hoskins (2013) measured the effect size of critical thinking skills by comparing the average scores of students' pretests and posttests. The research by Granger et al. (2012) examined the effects of student-centered learning and teachercentered learning on students' understanding of the science space concept. The research conducted becomes the basis for a further evaluation study of the effect size analysis in the implementation of a learning model towards learning results.

There have been many kinds of research investigating the differences or the correlation between variables in biology learning using particular learning models. However, the research on the statistical significance and effect size analysis carried out simultaneously has not frequently conducted. This article describes the analysis results of statistical significance and effect size related to critical thinking skills and creative thinking skills through the implementation of different learning types, namely Problem-Oriented Project-Based Learning integrated with Student Team Achievement Division (POPBLSTAD), Problem-Oriented Project-Based Learning (POPBL), Student Team Achievement Division (STAD) learning, and conventional learning.

Regarding the effect size analysis, several analysis tools can use Cohen (1988), and Maher et al. (2013) explained that in measuring effect sizes, such as related to ANOVA analysis, covariance analysis (ANCOVA), and multivariate covariate analysis (MANCOVA), the results were Eta-squared and Partial Eta-Squared. Some people consider that the eta-squared measurement is a better measure to be reported because it describes a variant calculated by independent measures (Levine \& Hullett, 2002). In this research, one way ANCOVA was used to determine the effectiveness of the implementation of three different learning models towards students' critical thinking skills and creative thinking skills in biology learning. In this regard, the effect size analysis uses to determine the effect size value of each learning model by looking at the levels of difference in the effect size value of each research variable.

Based on the description above, this research aims at analyzing how much is the effect size of four different learning types viewed from the differences in the value of students' critical thinking skills and creative thinking skills in Biology learning of Senior High Schools in Sumbawa, Indonesia.

\section{Literature Review}

\section{Critical Thinking Skills}

The critical thinking skills used in this research refer to the indicators developed by Ennis (1996), which abbreviated as FRISCO (Focus, Reason, Inference, Situation, and Overview). Critical thinking is the ability to think rationally and reflectively to focus on deciding what to believe and what to do (Ennis, 2011). Critical thinking involves the ability to draw appropriate conclusions, identify relationships, analyze probabilities, make predictions and logical decisions, and solve complex problems (Halpern, 2011; Pascarella \& Terenzini, 2005). Critical thinking consists of interpretation and evaluation skills in observation, communication, and information acquisition (Che, 2002; Wang \& Zheng, 2016). Critical thinking also includes the ability to interpret, analyze, evaluate, infer, and explain information as well as to regulate self (Facione, 1990). Critical 
thinking is strongly associated with student academic achievement (Carter, Creedy, \& Sidebotham, 2017), helping students to learn and adapt to any global changes (Ongardwanich, Kanjanawasee, \& Tuipae, 2015).

Research shows that the majority of students in Indonesia have not been able to think critically. In particular, Mahanal, Zubaidah, Bahri, \& Dinnurriya (2016) have revealed that students have not empowered to think critically in Biology. As a result, the students perform poor critical thinking skills (Sulasih, Suparmi, \& Sarwanto, 2017). Surveys conducted in several countries also put students into the middle to the low level of achievement in critical thinking (Demirhan \& Köklükaya, 2014; Forawi, 2016). Similarly, Zubaidah \& Mahanal (2015) reported that most of the students in middle schools had not developed critical thinking skills and thus were categorized into poor critical thinkers.

Students' lack of skills in critical thinking can be due to the implementation of conventional, lecturing-oriented, and test-oriented learning methods (Corebima, 2009). Learning activities mostly dominated by conventional methods having a minor contribution to students' critical thinking development (Hasan, Tumbel \& Corebima, 2013; Muhlisin, Susilo, Amin, \& Rochman, 2016). Facts show that instead of being encouraged to build knowledge and interpret meaning, students merely trained to listen and memorize information (Taale, 2013; Gambari, Shittu, \& Taiwo, 2016). Therefore, students are not actively involved in the critical thinking process (Mc Cormick, Clark, \& Raines, 2016).

\section{Creative Thinking Skills}

The creative thinking skills used in this research, refer to the indicators developed by Treffinger (2002), which include fluency, flexibility, originality, elaboration, and metaphorical thinking. Creative thinking can defined as the ability to discover truth, problems, ideas, and solutions to the problems (Sheu \& Chen, 2014). Some experts refer creative thinking to a whole set of cognitive activities used by individuals in certain conditions to react to the object of the problem based on their capacity (Birgili, 2015). Creative thinking includes the ability to understand an object, test a hypothesis, and communicate investigation results. Creative thinking represents a mental process that involves cognitive processing (Böckers \& Mayer, 2014). Creative thinking skills play a significant role in supporting individuals to broaden as well as create knowledge and ideas (Louca, Marouchou, Mihai, \& Konis, 2014). The results of the study indicate that the empowerment of creative thinking skills in Indonesia is still low. The research conducted by Yusnaini et al. (2017) reported that the average creative thinking skills of the students taught by using traditional learning were $36.18 \%$, classified as low criteria.

\section{Problem-Oriented Project-Based Learning}

Problem-Oriented Project Based Learning (POPBL) is a collaborative learning model that combined project activities and problem-based learning (Rongbutsri, 2017). POPBL is one of the types of PBL (Kolmos \& Graaff, 2014). POPBL is contextual (Strobel \& Baneveld 2009) and can support sustainable education (Yasin \& Rahman, 2011) and the development of students' creative thinking and soft skills (Yasin, \& 
Mustofah, 2008; Latada \& Kassim, 2017). The principles of POPBL are problemoriented, work in projects, interdisciplinary, student-oriented, and cooperative (Kolmos, Fink, \& Krogh, 2004; Barge, 2010). Despite its benefits, this model also has some limitations in its practice, such as project tasks only cover a small part of the curriculum core, the characteristics of the materials that can project are likely particular, and the tasks are professional realistic and significant (Nayan, 2014). Besides, there are no material explanations at the beginning of the lesson; students directly guided to work in groups, learning activities are the responsibility of the teacher, providing the opportunity for traditional learning methods to occur in the classroom repeatedly (Rongbutsri, 2017).

\section{Student Team Achievement Division}

Student Team Achievement Division (STAD) is a practical and straightforward cooperative learning model that is most often adopted by teachers in schools (Wyk, 2013). STAD emphasizes classroom interactions that allow students to work together, motivate, and help each other in understanding learning materials to achieve learning objectives (Zubaidah, 2013). STAD is carried out in five stages, that are classroom presentation, group work, quiz assignment, evaluation, and reward (Slavin, 2005). STAD is appropriate for Biology learning since Biology contains many concepts that require solutions through group discussion and group work (Wulandari et al., 2017). Considering this beneficial quality of STAD, therefore, project-oriented problemsolving can combine with STAD. Research shows that the integration of this learning model can empower students to think critically and creatively (Gunawan, 2016). The integration of the POPBL (Problem-Oriented Project-Based Learning) and STAD (Student Team Achievement Division) learning models expected to complement each other. The integration of these two learning models is named POPBLSTAD.

\section{Aim of the Research}

This research aimed to investigate the effect size of different learning types, namely the learning models of POPBL, STAD, POPBLSTAD, and conventional learning on students' critical and creative thinking skills in Biology.

\section{METHOD}

\section{Research Design and Participant}

This research was preceded by quasi-experimental research that analyzing the differences in critical thinking skills and creative thinking skills of the students taught by using four different learning types, namely POPBLSTAD, POPBL, STAD, and conventional learnings. The design used in this research was Pretest-Posttest Nonequivalent Control Group Design. After that, the effect size test carried out on different learning types towards the achievement of students' critical thinking skills and creative thinking skills as a continuation of the experimental research. The interpretation of the effect size used in this research referred to Cohen's standardization $(1988,1992)$, which included 0.10 as low interpretation, 0.30 as moderate interpretation, and 0.50 as a great interpretation. 
The total participant in this research were 129 students. The participant was selected using random sampling. The research samples were determined randomly based on the results of the placement test. Similarly, the classes used as the research location were also determined based on the results of the placement test related. After the placement test administered, four classes obtained from State Senior High School 1 Moyo Utara, State Senior High School 1 Moyo Hulu, State Senior High School 1 Alas, and State Senior High School 1 Lape. This research was conducted from January to June 2018 on the class X students of Senior High School in Sumbawa, Indonesia, based on the research design, as indicated in Table 1.

Table 1

Research design

\begin{tabular}{llllll}
\hline Pretest & $\begin{array}{l}\text { Treatment } \\
\text { Group }\end{array}$ & Name of school & Class & $\begin{array}{l}\text { Number of } \\
\text { students }\end{array}$ & Posttest \\
\hline $\mathrm{O}_{1}$ & POPBLSTAD & SMAN 1 Moyo Utara & X IPA 1 & 36 & $\mathrm{O}_{2}$ \\
\hline $\mathrm{O}_{3}$ & POPBL & SMAN 1 Moyo Hulu & X IPA 2 & 32 & $\mathrm{O}_{4}$ \\
\hline $\mathrm{O}_{5}$ & STAD & SMAN 1 Lape & X IPA 4 & 30 & $\mathrm{O}_{6}$ \\
\hline $\mathrm{O}_{7}$ & Conventional & SMAN 1 Alas & X IPA 2 & 31 & $\mathrm{O}_{8}$ \\
\hline
\end{tabular}

\section{Procedures}

To review the importance of statistical significance and effect size tests in this research, the process of quasi-experimental research, which had previously carried out, is presented as the basis for the LSD and the effect size testing. The quasi-experimental research consisted of four learning classes taught by using different learning types. In the experimental class, the students taught by using the POPBLSTAD learning model, in the positive control class 1 the students were taught by using the POPBL learning model, in the positive control class 2 the students were taught by using the STAD learning model, and in the conventional learning class, the students were taught by the school teacher without any intervention from the researcher. The research design used in the previous research was a Pretest-Postest Nonequivalent Control Group Design. The topics of the learning materials were Plantae, Animalia, ecology, and environmental change.

\section{Instrument}

The instrument used to measure critical thinking skills and creative thinking skills in this research was an essay test. The results of the test then measured by using a critical thinking skill rubric integrated with an essay test developed by Zubaidah, Corebima, Mahanal, \& Mistianah (2018), which modified from Finken \& Ennis (1996). The results of the creative thinking skill test measured by using the Treffinger rubric (2002). The test instruments in this research had initially tested for validity and reliability. The results of the validity and reliability tests indicate that the essay tests were valid and reliable.

\section{Data Analysis}

The data of this research analyzed by using ANCOVA continued by the LSD test to determine the differences in critical thinking skills and creative thinking skills of the 
students taught by using different learning types. Before the hypothesis testing carried out, a prerequisite test administered consisted of a normality test and a homogeneity test. The results of the normality test indicated that the data usually distributed, and the results of the homogeneity test suggest that the data are homogeneous. Furthermore, to find out the effect size of different learning types on critical thinking skills and creative thinking skills, an effect size test per two variables referring to Cohen (1988) was used.

\section{FINDINGS}

\section{The Results of LSD Test on critical Thinking Skills based on Learning Types}

The results of the quasi-experimental research analyzed by using ANCOVA show that the implementation of different learning types had a significant effect on the students' critical thinking skills and creative thinking skills. The POPBLSTAD model had the highest achievement of critical thinking skills and creative thinking skills, which was significantly higher than those of the other three learnings. The achievement of critical thinking skills and creative thinking skills between POPBL and STAD learning models was not significantly different, while the conventional learning had the lowest achievement of critical thinking skills and creative thinking skills, which was significantly lower than those of the other three learnings.

Table 2 shows a summary of the results of the LSD test related to the different learnings towards the achievement of students' critical thinking skills. Table 3 shows a summary result of the effect size test on the critical thinking skills of students taught by using different learnings.

The results of the LSD test in Table 2 show that the critical thinking skills of the students taught by using the POPBLSTAD model are higher than those of the students taught by using the POPBL model with a difference of $16.11 \%$, higher than those taught by using the STAD model with a difference of $21.22 \%$, and higher than those taught by using the conventional learning with a difference of $39.38 \%$. There is no significant difference in the students' critical thinking skills between POPBL and STAD models; the difference between the POPBL model and conventional learning is $20.04 \%$, and the difference between the STAD model and conventional learning is $14.98 \%$. It can conclude that the POPBLSTAD model has the highest potency to empower the students' critical thinking compared to the other three learnings.

Table 2

Summary of the results of LSD test related to students' critical thinking skills

\begin{tabular}{lllllll}
\hline Class & Pretest & $\begin{array}{l}\text { Post- } \\
\text { test }\end{array}$ & Difference & Average Score Correction & $\begin{array}{l}\text { LSD } \\
\text { Notation }\end{array}$ \\
\hline POPBLSTAD & 32.806 & 73.222 & 40.417 & 72.912 & $\mathrm{a}$ & \\
\hline POPBL & 31.062 & 62.812 & 31,750 & 62.791 & $\mathrm{~b}$ \\
\hline STAD & 30.867 & 60.133 & 29.267 & 60.144 & $\mathrm{~b}$ \\
\hline Conventional & 28.677 & 51.935 & 23.258 & 52.308 & & $\mathrm{c}$ \\
\hline
\end{tabular}


The summary in Table 3 shows that the value of the effect size of the critical thinking skills of the students taught by using the POPBLSTAD learning model compared to STAD model is 0.68 (high criteria), compared to POPBL model is 0.65 (high criteria), and compared to the conventional learning is 0.82 (high criteria). The effect size value of STAD compared to the POPBL learning model is -0.19 (low); it is following the fact that there is not any significant difference between the two learning models. The effect size of the STAD model compared to conventional learning is 0.46 (medium criteria), and that of the POPBL learning model compared to conventional learning is 0.60 (high criteria). Based on the results of the LSD test in Table 2 and the results of the effect size test in Table 3, it can conclude that the interpretation of the achievement of critical thinking skills of the students taught by using different learnings is inline between the two kinds of test.

Table 3

Summary of effect size test of each two learning types related students' critical thinking skills

\begin{tabular}{llll}
\hline Learning & Cohen's & Effect Size & Criteria \\
\hline POPBLSTAD-STAD & 1.86 & 0.68 & High \\
\hline POPBLSTAD-POPBL & 1.72 & 0.65 & High \\
\hline POPBLSTAD-Conventional & 2.86 & 0.82 & High \\
\hline POPBL and STAD & -0.40 & -0.19 & Low \\
\hline STAD-Conventional & 1.02 & 0.46 & Medium \\
\hline POPBL-Conventional & 1.52 & 0.60 & High \\
\hline
\end{tabular}

The Results of LSD Test on Students' creative Thinking Skills based on Learning Types

Table 4 shows a summary of the results of the LSD test related to the different learnings towards the achievement of students' creative thinking skills. Table 5shows the summary results of the effect size test on the creative thinking skills taught by using different learnings. The results of LSD test in Table 4 show that the creative thinking skills of the students taught by using the POPBLSTAD model are higher than those of the students taught by using the STAD model with a difference of $25.91 \%$, than those of the students taught by using the POPBL model with a difference of $18.57 \%$, and than those of the students taught by using the conventional learning with a difference of $53.29 \%$.

Table 4

Summary of the results of LSD test related to students' creative thinking skills

\begin{tabular}{lllllll}
\hline Class & Pretest & $\begin{array}{l}\text { Post- } \\
\text { test }\end{array}$ & Difference & $\begin{array}{l}\text { Corrected Average } \\
\text { Score }\end{array}$ & LSD Notation \\
\hline POPBLSTAD & 30.354 & 70.208 & 39.854 & 70.067 & $\mathrm{a}$ & \\
\hline POPBL & 30.156 & 59.180 & 29.023 & 59.090 & $\mathrm{~b}$ \\
\hline STAD & 30.042 & 55.708 & 25.667 & 55.648 & $\mathrm{~b}$ \\
\hline Conventional & 28.589 & 45.443 & 16.855 & 45.759 & $\mathrm{c}$ \\
\hline
\end{tabular}

The POPBL model and STAD model have a difference of $6.18 \%$, the POPBL model, and the conventional learning have a difference of $29.13 \%$, and the STAD model and 
the conventional learning have a difference of $21.61 \%$. It s seen that the POPBLSTAD model has the highest difference compared to the other three learnings

Table 5

The summary of effect size test of each two learning types related to students' creative thinking skills

\begin{tabular}{llll}
\hline Learning & Cohen's & Effect Size & Criteria \\
\hline POPBLSTAD-STAD & 1.75 & 0.66 & High \\
\hline POPBLSTAD-POPBL & 1.31 & 0.55 & High \\
\hline POPBLSTAD-Conventional & 2.97 & 0.83 & High \\
\hline POPBL and STAD & -0.43 & -0.21 & Low \\
\hline STAD-Conventional & 1.29 & 0.54 & High \\
\hline POPBL-Conventional & 1.69 & 0.65 & High \\
\hline
\end{tabular}

The results of the effect size analysis in Table 5 show that the POPBLSTAD learning model has a higher effect size than the STAD learning model with a value of 0.66 (high criteria), compared to POPBL learning model the combined learning model has a value of effect size as much as 0.55 (high criteria) and compared to conventional learning the combined learning model has a value of effect size as much as 0.83 (high criteria). The STAD model has a higher effect size than conventional learning as much as 0.54 (high criteria). The POPBL learning model has a higher effect size than conventional learning as much as 0.65 (high criteria). On the other hand, the POPBL model and the STAD model has an effect size value of -0.21 (low criteria).

The results of the LSD analysis and the results of the effect size test show that the class taught by using the POPBLSTAD learning model has a difference and a higher effect size value than the classes taught by using the other learning. It can be concluded too that the results of both analyses are in line, having the same interpretation.

\section{DISCUSSION}

\section{Students' critical Thinking Skills related to Learning Types based on LSD Test}

The results of the ANCOVA LSD test (Table 2) show that the four learnings implemented have a significantly different achievement of critical thinking skills. In general, the POPBLSTAD model has the achievement of critical thinking skills, which is significantly higher than the other three learnings. The critical thinking skills of the students taught by using the POPBLSTAD learning model are $21.22 \%$ higher than those of the students taught by using the STAD learning model, $16.11 \%$ higher than those of the students taught by using the POPBL learning model, and $39.38 \%$ higher than those of the students taught by using the conventional learning. The high critical thinking skill score of the students in the POPBLSTAD model class in this research caused by the fact that the students were involved in problem formulation activities. Vieira \& Vieira (2016) explained that students' critical thinking skills could improve through learning experiences. The learning experience in the POPBLSTAD class is related to the problem formulation activities. This is in line with Pater (2012), stating that critical thinking skills can improve through problem formulation activities. Besides, Wulandari, Amin, Zubaidah, \& Al-muhdar (2017) revealed that class presentation activities aimed 
to empower students' analyzing, synthesizing, and evaluating ability, to foster their critical thinking skills.

The other stages of the POPBLSTAD learning model that can improve the students' critical thinking skills are the implementation of investigative group activities outside of class time and problem-solving activities. At this stage, the students required to be able to connect theoretical knowledge with broader concepts of knowledge in order to support the data collection and data analysis activities to support scientific inquiry activities. Jurecka \& Wander (2013) stated that scientific activities had a statistically positive effect on the improvement of students' critical thinking skills. Besides, through problem-solving activities, the students are trained to do analyzing and evaluating activities, which can improve their critical thinking and problem-solving skills. The students who have excellent critical thinking skills will be able to do analyzing, synthesizing, and evaluating activities to solve problems (Duron, Limbach \& Waugh, 2006).

This result is in line with the research results conducted by many researchers before (Mahanal, Zubaidah, Bahri, \& Dinnurriyah 2016; Supratman, Almuhdar \& Ibrohim 2013; Husamah \& Pantiwati, 2016; Fuad, Zubaidah, Mahanal, \& Suarsini, 2016; Wulandari, Amin, Zubaidah, \& Almuhdar, 2017). Other research investigating the effectiveness of three different learning models conducted by Fitriani, Zubaidah, Susilo \& Al-Muhdar (2020). The research reported that the implementation of the learning models had a significant effect on students' critical thinking skills in biology learning. Critical thinking skills could develop through the learning process (Bart, 2010; Niu, Behar, Horenstein, \& Garvan, 2013). According to Shim and Walczak (2012), the implementation of learning models provides an opportunity to support the development of students' critical thinking skills. Duron, Limbach, \& Waugh (2006) stated that students would be able to think critically well when they could carry out the process of analysis, synthesis, and evaluation in learning. Therefore, according to Corebima (2006), the empowerment of critical thinking skills must be intentionally done in every learning process.

\section{Effect Size Test of Learning Types related to Students' Critical Thinking Skills}

The results of the effect size test on the critical thinking skills using different learnings (Table 2) show that the integration of the POPBLSTAD model has the highest effect size than that of the other three learnings. This can be seen from the effect size value of the POPBLSTAD, which was 0.68 higher than that of the STAD model, 0.65 higher than that of the POPBL model, and 0.82 higher than that of the conventional learning. The effect size between the STAD model and conventional learning is 0.46 with moderate interpretation, between the POPBL and conventional learning is 0.60 with great interpretation. This is different from that between POPBL and STAD learning models, which had a negative effect size value of -0.19 with low interpretation. The low effect size value between the two learning models is in line with the information obtained from the results of the ANCOVA LSD test (Table 2), showing that POPBL and 
STAD have the same notation, which indicates that the results of the statistical analysis are not significantly different.

The results of this research indicate that the integration POPBLSTAD learning model has an effect size with a higher interpretation compared to the other three learnings towards the achievement of students' critical thinking skills. This result is in line with the research results of Quitadmo \& Kurtz (2013) and Fuad at al. (2016) reporting that the application of learning models had a higher effect size on the achievement of students' critical thinking skills than that of the students taught by using the conventional learning. The research by Tran (2013) showed that the integration of learning models was proven to be effective in improving students' critical thinking skills; on the other hand, the conventional learning is proven not to empower students' critical thinking skills (Bahri, Corebima, Amin, \& Zubaidah, 2016; Anwar et al., 2019). Cohen (1988) stated that the higher the effect size value, the greater the effect on the changes in students' learning results.

Maher et al. (2013) explained that there were two categories to measure the effect size of quantitative research, namely (1) comparing two or more groups, and (2) determining the strength of the correlation between variables. Related to this research, comparing the results of the statistical significance test and the effect size of the students 'critical thinking skills and students' creative thinking skills are included in the first category. Several research results are in line with the results of this research, such as the research by Gottesman \& Hoskins (2013) which reported that the results of the Critical Thinking Assessment Test (CAT) in different learning approaches have the overall scores of the posttest increase in high effect sizes (0.97).

The research results of Abraham et al. (2012) reported that the implementation of learning treatments had a significant effect and had a high effect size value on the students' conception achievement of evolutionary learning material. Granger et al. (2012) also reported that student-centered learning approaches had a greater effect size than teacher-centered learning approaches to the improvement of students' understanding of the science space concept. The research conducted by Anwar et al. (2019) reported that there was a difference in the effect size value of two different learning models on the achievement of temperature and heat concept mastery of senior high school students.

Based on the research results above, It is revealed that the results of the effect size test can provide complete statistical analysis information. This is in line with Huberty (2002), stating that the application of effect size is essential to provide information for the researchers about findings in a practical and meaningful manner. The application of effect size to complement the statistical significance test has become a high-impact process in updating the information of statistical significance (Tressoldi, Giofre, Sella \& Cumming 2013).

\section{Students' creative Thinking Skills related to Learning Types based on LSD Test}

The results of the ANCOVA LSD test show that there is a significant difference in creative thinking skills between the students taught by using the POPBLSTAD, POPBL, 
STAD, and conventional learning (Table 3). The results of the ANCOVA LSD test show that the creative thinking skill values of the students taught by using the POPBLSTAD model are $25.91 \%$ higher than those of the students taught by using the STAD learning model, $18.57 \%$ higher than those of the students taught by using the POPBL learning model, and 53.29\% higher than those of the students taught by using the conventional learning. The POPBL model and STAD model have a difference of $6.18 \%$, the POPBL model, and the conventional learning have a difference of $29.13 \%$, and the STAD model and the conventional learning have a difference of $21.61 \%$. It can see that the students' creative thinking skills value uncovered at the POPBLSTAD model is the highest one compared to that found at the three other learnings implemented. The main reason was supporting the improvement of students' creative thinking skills in the POPBLSTAD class caused by the fact that the students' focus maintained in doing group work activities and solving problems collaboratively. Collaborative work activities can improve students' academic improvement, such as students' creative thinking skills (Yusnaini, Corebima, Susilo \& Zuabidah, (2017). The interaction which occurs in the learning groups can trigger students' cognitive conflict to do creative thinking processes (Huang, 2017). This result is following the research findings of Awang \& Ramly (2008), Yusnaini, Corebima, Susilo, \& Zubaidah (2017), Unglar (2018), and Hidayati, Zubaidah, Suarsini \& Praherdhiono (2019) which reported that problem-solving oriented learning models had proven to have a significant effect on the achievement of students' creative thinking skills and student creativity.

\section{Effect Size Test of Learning Types related to Students' creative Thinking Skills}

The results of the effect size test on students' creative thinking skills using different learning types indicate that the POPBLSTAD learning model has the most significant effect of the four learnings implemented (learning models of POPBLSTAD, STAD, and POPBL as well as Conventional learning). This finding is by the research results conducted by Birgili (2015), Lince (2016), and Hu, Wu \& Shieh (2016) which reported that the students taught by using learning models potentially had higher creative thinking skills effect than the students taught by using conventional learning. Kuo, Chen, \& Hwang (2014) stated that problem-oriented learning models could empower students' creative thinking skills. Hargrove (2007) reported that cooperative learning could encourage the development of students' creative thinking skills. Blakey \& Spence (1990) stated that problem-solving activities could develop students' creative thinking skills.

The increase in students' creative thinking skills is probably due to the role of STAD involved in the POPBLSTAD learning model. The integration of STAD complements the POPBL learning model. The implementation of the POPBL model in STAD learning provides the students the opportunity to learn independently and to interact with peers. According to Schunk (2008), independent learning is the ability to control and understand the learning environment itself, including choosing the right strategy to achieve goals. Wheeler, Waite \& Bromfield (2002) stated that students could develop their creative thinking skills if the learning environment could provide opportunities to develop their innovative ideas. Through problem-oriented project learning, the students' creative ideas will develop along the learning process because the main characteristics 
of integrated POPBLSTAD are collaborative activities, problem-solving, and studentcentered project activities.

\section{CONCLUSIONS}

The results of the effect size test conducted at each two learning show that the effect size values have criteria of high and low. The POPBLSTAD model has the highest effect size values compared to the other three learnings (POPBL, STAD, and conventional learning). The information obtained from the results of the effect size test in this research is in line with the results of the ANCOVA LSD test showing that the POPBLSTAD has the highest scores of students' critical and creative thinking skills compared to the those found at the three other learnings.

The effect size test has some advantages in that the information obtained from this kind of test is closely related to the qualifications of data analysis results, or those are commonly known as the interpretation of the results of the statistical significance test. While the ANCOVA LSD test does not discuss the qualification of statistical significance, but it explains the quantification of the results of the statistical significance test. By knowing the effect size of a learning model, educators can select the most appropriate learning models for their teaching and learning activities. Therefore, through this kind of research, it is expected that future researchers not only present the results of statistical significance test or only present the results of the effect size test, but both test types need to be simultaneously done in order that the information obtained can complement each other because the results of each type of these test have some advantages and disadvantages. The information obtained from the effect size test result can strengthen the results of the statistical significance test in any quantitative research.

\section{ACKNOWLEDGMENTS}

The researcher thanks to the Ministry of Research, Technology, and Higher Education, as wells as to BUDI-DN and to LPDP (Indonesia Endowment Fund for Education), which have become the sponsor, and all parties who have participated in the completion of this research. Criticisms and suggestions are needed further. This article expected to be useful for readers.

\section{REFERENCES}

Abraham, J. K., Perez, K. E., Downey, N., Herron, J. C., \& Meir, E. (2012). Short lesson plan associated with increased acceptance of evolutionary theory and potential change in three alternate conceptions of macroevolution in undergraduate students. $C B E$ Life Sci Educ, 11, 152-164.

Andersen, A. S., \& Kjeldsen, T. H. (2015). A Critical Review of the Key Concepts in PPL. In The Roskilde Model: Problem Oriented Learning and Project Work (pp 3-16). Springer.

Anwar, C., Siregar, A., Yuberti, Zellia, Widiyanti, W., Diani, R., \& Wekke, I. S. (2019). Effect Size Test of Learning Model ARIAS and PBL: Concept Mastery of Temperature 
and Heat on Senior High School Students. EURASIA Journal of Mathematics, Science and Technology Education, 15(3), 2-9.

Awang, H., \& Ramly, I. (2008). Creative thinking skill approach through problem based learning: pedagogy and practice in the engineering classroom. International Journal of Human and Science, 3(1), 18-23.

Bahri, A., Corebima, A. D., Amin, M., \& Zubaidah, S. (2016). Potensi Strategi Problem Based Learning (PBL) Terintegrasi Reading Questioning and Answering (RQA) untuk meningkatkan Hasil Belajar Kogintif Mahasiswa Berkemampuan Akademik Berbeda. [The potential of Problem-based Learning (PBL)integrated with Reading Questioning And Answering (RQA) strategy to improve the cognitive learning results of different academic ability students. Jurnal Pendidikan Sains, 4(2), 49-59.

Balow, C. (2017). The Effect Size in Educational Research: What is it \& How to Use it? www.linkedin.com/pulse/effect-size-educational-research-what-how-use-below-ph-d(accessed 22 July 2018).

Barge, S, 2010 Prinsiple Of Problem and Project Based Learning: The Aalborg PBL Models: Aalborg University, 1-24.

Bart, N. (2010). Thinking critically about Critical Thinking in Higher Education. International Journal for the Scholarship of Teaching and Learning, 4(2), 1-18.

Birgili, B. (2015). Creative and Critical Thinking Skills in Problem-based Learning Environments. Journal of Gifted Education and Creativity, 2(2), 71-80.

Blakey, E., \& Spence, S. (1990). Developing metacognition. ERIC Reproduction Services No ED327218. Retrieved from http://www.eric.ed.gov/PDFS/ ED327218.pdf

Böckers A. Mayer C. And Böckers T. M., (2014). Does learning in the clinical context in anatomical sciences improve examination results, learning motivation, or learning orientation?. Anatomical sciences education, 7(1), 3-11.

Carter, A. G., Creedy, D. K., \& Sidebotham, M. (2017). Critical Thinking evaluation in reflection writing: Development and testing of Carter Assessment of Critical thinking in Midwifery (Reflection). Midwifery, 54, 73-80. https://doi.org/10.1016/j.midw. 2017.08.003

Che, F.S. (2002). Teaching critical thinking skills in Hong Kong secondary school. Asia Pacific Education Review, 3(1), 83-91.https://doi.org/10.1007/BF03024923

Coe, R. (2002). It's the effect size, stupid: what effect size is and why it is important. Paper presented at the Annual Conference of the British Educational Research Association, held 12-14 September 2002, at the University of Exeter, UK. www.leeds.ac.uk/educol/ documents/00002182.htm (accessed 5 March 2019).

Cohen, J. (1988). Statistical Power Analysis for the Behavioral Sciences, 2nd ed., Hillsdale, NJ: Lawrence Erlbaum.

Cohen, J. (1992). A power primer. Psychol Bull, 112, 155-159. 
Corebima, A. D. (2006). Biology learning which empowers students' thinking skills]. A paper presented at Metacognitive Strategy Training on Biology Learning for Senior high School Biology Teachers in Palangkaraya City, 23 August 2006.

Corebima, A.D. (2009). Pengalaman Berupaya Menjadi Guru Profesional, Pidato Pengukuhan Guru Besar Dalam Bidang Genetika. Malang. FMIPA Universitas Negeri Malang.

Demirhan, E.,\& \& Koklukaya A.D. (2014). The Critical Thinking Dispositions of Prospective Science Teachers. $5^{\text {th }}$ World Conference on Educational Sciences. ProcediaSocial and Behavioral Sciences, 116, 1551-1555. DOI: 10.1016/j.sbspro.2014.01.433

Duron, R., Limbach, B., \& Waugh, W. (2006). Critical Thinking Framework For Any Discipline. International Journal of Teaching and Learning in Higher Education. 17(2), 160-166.

Ellis, P.D. (2010). Effect Sizes and the interpretation of research results in international business. Journal of International Business Studies, 41, 1581-1588.

Ennis, R.H. (2011). The Nature Of Critical Thinking: An Outline Of Critical Thinking Dispositions and Abilities. Retrieved From http:// education. Illinois.edu/docs/defaultsource/faculty-documents/Robert-ennis/thenatureofcriticalthinking_51711_000.pdf.

Ennis, R. H. (1996). Critical Thinking. Upper Saddle River, New Jersey: Prentice-Hall

Facione, P. (1990). Critical thinking: A statement of expert consensus for purposes of educational assessment and instruction (The Delphi Report).

Fan, X. (2001). Statistical significance and effect size in education research: two sides of a coin. J Educ Res, 94, 275-282.

Ferguson, C. J. (2009). An effect size primer: a guide for clinicians and researchers. Prof Psychol Res Pract, 40, 532-538.

Fuad, N. M., Zubaidah, S., Mahanal S., \& Suarsini, E. (2017). Improving Junior High Schools' Critical Thinking Skills Based on Test Three Different Models of Learning. International Journal of Instruction, 10(1), 101-116.

Forawi, S. (2016). Standard-based science education and critical thinking. Thinking Skills and Creativity. doi.org/10.1016/j.tsc.2016.02.005

Fitriani, A., Zubaidah, S., Susilo, H., \& Al Muhdhar, M. H. I. (2020). PBLPOE: A Learning Model to Enhance Students' Critical Thinking Skills and Scientific Attitudes. $\begin{array}{llll}\text { International Journal of Instruction, } & \text { 13(2), }\end{array}$ https://doi.org/10.29333/iji.2020.1327a

Gambari, A.I., Shittu A.T., \& Taiwo, O.A. (2016). Enhancing Students' Understanding of Algebra Concepts through Cooperative Computer Instruction. Pedagogical Research,1(2), 55. 
Gottesman, A. J., \& Hoskins, S.G. (2013). CREATE Cornerstone: Introduction to Scientific Thinking, a new course for STEM-interested freshmen, demystifies scientific thinking through analysis of scientific literature. CBE Life Sci Educ, 12, 59-72.

Granger, E. M., Bevis, T. H., Saka, Y., Southerland, S. A., Sampson, V., \& Tate R. L. (2012). The efficacy of student-centered instruction in supporting science learning. Science, 338, 105-108.

Gunawan, Harjono and Nisrina, 2016 Improving students' creativity using cooperative learning with virtual media on static fluida concept. International Conference on Science Education, 1-7.

Halpern, D. F. (2011). Critical Thinking Workshop for Helping Our Students Become Better Thinker.

Hargrove, R. A. (2013). Assessing the long-term impact of a metacognitive approach to creative skill development. International Journal Technol Des Educ, 23(3), 489-517 DOI:10.1007/s10798-011-9200-6.

Hasan, S., Tumbel, F.M., \& Corebima, A.D. (2013). Empowering Critical Thinking Skills in Indonesia Archipelago: Study on Elementary School Students in Ternate. Journal Of Modern Education Review, 3(11), 852-858.

Hidayati, N., Zubaidah, S., Suarsini E., \& Praherdhiono (2019). The Integrated PBLDMM: A Learning Model to Enhance Student Creativity. Pedagogika, 135(3), 163-187.

Hojat, M., Xu, G. (2004). A visitor's guide to effect sizes-statistical significance versus practical (clinical) importance of research findings. Adv. Health Sci. Educ, 9, 241-249.

Huang, P.S. (2017). An Exploratory Study on Remote Associates Problem solving: Evidence of Eye Movement Indicators. Thinking Skills and Creativyty, 24, 63-72. Htpps://doi.org/10.1016/j.tsc.2017.02.004

Hu, R., Wu, Y. Y. \& Shieh, C. J. (2016). Effects of Virtual Reality Integrated Creative Thinking Instruction on Students' Creative Thinking Abilities. Eurasia Journal of Mathematics, Science \& Technology Education, 12(3), 477- 486.

Husamah \& Pantiwati, Y. (2014). Cooperative Learning STAD-PjBL: Motivation, Thinking Skills, and Learning Outcomes of Biology Department Students. International Journal of Education Learning and Development, 2(1), 77-94.

Huberty, C. J. (2002). A history of effect size indices. Educ Psychol Meas, 62, 227-240.

Jurecki, K. \& Wander, M. C. F. (2012). Science literacy, critical thinking, and scientific literature: Guidelines for evaluating scientific literature in the classroom. Journal of Geoscience Education, 60(2), 100-105.

Kolmos, A., De Graaff, 2014 Erik Problem-Based and Project-Based Learning in Engineering Education. Published in: Cambridge Handbook of Engineering Education Research. 141-160 
Kotrlik, J. W., \& Williams, H. A. (2003). The incorporation of effect size in information technology, learning, and performance research. Inform Technol Learn Perform, 21, 17.

Kotrlik, J. W., \& Williams, H. A \& Jabor (2011). Reporting and Interpreting Effect Size in Quantitative Agricultural Education Research. Journal of Agricultural Education, 52(1), 132-142.

Kuo, F. R., Chen, N. S., \& Hwang, G. J. (2014). A creative thinking approach to enhancing the web-based problem solving performance of university students. Computer and Education, 72, 220-230.

Kurniawati, Z, L. Zubaidah, S., \& Mahanal, S. (2015). Keterampilan berpikir kritis Siswa SMA Negeri Kota Batu Pada Mata Pelajaran Biologi. Makalah disajikan dalam seminar Nasional dan Workshop Nasional Biologi dan pembelajaran ke-2 Jurusan Biologi FMIPA UM.Malang.

Lakens, D. (2013). Calculating and reporting effect sizes to facilitate cumulative science: a practical primer for t-tests and ANOVAs. Frontiers in Psychology, 4, 1-12.

Latada and Kassim, (2017) Problem-oriented project-based learning (POPBL): an initiative to encourage soft skills expansion among students at a public University. Journal of global business and social entrepreneurship, 1(3), 75-83

Levine, T. R., \& Hullett. C. R., (2002). Eta squared, partial eta squared, and misreporting of effect size in communication research. Hum Commun Res, 28, 612-625.

Lince, R. (2016). Creative Thinking Ability to Increase Student Mathematical of Junior High School by Applying Models Numbered Heads Together. Journal of Education and Practice, 7(6), 206-212.

Louca. E. P, Marouchou, Mihai. S., \& Konis. E. (2014). Teaching for Creativity in Universities. Journal of Education and Human Development, 3(4), 131-154.

Mahanal, S., Zubaidah. S., Bahri. A. \& Dinnurriyah, M. S. (2016). Improving students' critical thinking skills through Remap NHT in biology classroom. Asia-Pacific Forum on Science Learning and Teaching, 17(2), 4-20.

Maher, J. M., Markey, J. C., \& Erbet-May, D. (2013). The Other Half of the Story: Effect Size Analysis in Quantitative Research. CBE_Life Sciences Education, 12, 345351.

Matthews, K. E., Adams, P., \& Goos, M. (2010). Using the principles of BIO2010 to develop an introductory, interdisciplinary course for biology students. CBE Life Sci Educ, 9, 290-297.

Mazen, A.M., Hemmasi, M., \& lewis, M.F. (1987). Assessment of statistical power in contemporary strategy research. Strategic Management Journal, 8(1), 403-410. doi.org/10.1002/smj.4250080410. 
Mc Cormick, N. J., Clark, L. M., \& Raines, J. M. (2016). Enganging Students in critical Thinking and Problem Solving: A Brief Review of the Literature. Journal of Studies in Education, 5(4), 100. http://doi.org/10.5296/jse.v5i4.8294.

Morris, F. E., \& Frit, C.O. (2013). Effect sizes in memory research. Psychology Department, Lancaster University, UK doi.org/10.1080/09658211.2013.763984. pp 112.

Muhlisin, Susilo H, Amin M, \& Rochman F. (2016). Improving critical thinking skills of college students through RMS model for learning basic concepts in science. AsiaPacific Forum on Science Learning and Teaching, 1(17), 1-24.

Nakagawa, S., \& Cuthill, I. C. (2007). Effect size, confidence interval, and statistical significance: a practical guide for biologists. Biol Rev Camb Philos Soc, 82, 591-605.

Niu, L., Behar, Horenstein, L., \& Garvan, C. W. (2013). Do instructional interventions influence college students' critical thinking skills? A meta-analysis. Educational Research Review, 9, 114-128. doi:org/10.1016/j.edurev.2012.12.002.

Ongardwanich. N., Kanjanawasee. S., Tuipae, C. (2015). Development of $21^{\text {st }}$ Century Skill Scales as Perceived by Students. Procedia - Social and Behavioral Sciences, 191, 737-741. Doi: 10.1016/j.sbspro.2015.04.716

Osbourne, J. (2008). Sweating the small stuff in educational psychology: how effect size and power reporting failed to change from 1969 to 1999 and what that means for the future of changing practices. Educ Psychol, 28, 151-160.

Pascarella, E. T., \& Terenzini, P. T. (2005). How college affects students: A third decade of research San Francisco: Jossey-Bass.

Peter, E. (2012). Critical thinking: essence for teaching mathematics and mathematics problem solving skills. African Journal of Mathematics and Computer Science Research, 5(3), 39-43. https://doi.org/10.5897/AJMCSR11.161.

Quitadamo, I. J., \& Kurtz, M. J. (2007). Learning to improve: using writing to increase critical thinking performance in general education biology. CBE Life Sci Educ, 6, 140154.

Rongbutsri, N. (2017). Students Using Online Collaborative Tools in Problem-Oriented Project Based Learning (POPBL) Aalborg Universitetsforlag. Ph.d.-serien for Det Humanistiske Fakultet, Aalborg Universitet, DOI10.5278/vbn.phd.hum.00072

Schunk, D. H. (2008). Metacognition, self-regulation, and self-regulated learning: Research recommendation. Educational Psychology Review, 20(4), 463-467.

Sheu, F. R., \& Chen, N. S. (2014). Taking a signal: A review of gesture-based computing research in education. Computers \& Education, 78, 268-277. 
Shim, W., \& Walczak, K. (2012). The impact of Faculty Teaching Practices on the Development of Students' Critical Thinking Skills. International Journal of Teaching and Learning in Higher Education, 2(4), 16-30.

Slavin, R. E. (2005). Show Me The Evidence. Effective Program For Elementary and secondary schools. US. Johns Hopkins University.

Strobel, J \& Barneveld, A, 2009 When is PBL more effective? A meta-synthesis of meta-analyses comparing PBL to conventional classrooms. The Interdisciplinary Journal Of Problem-Based Learning, 3(1), 44-58.

Sulasih, Suparmi, A.,\& Sarwanto. (2017). Profil Of Student Critical Thinking ability on static fluid concept. Journal of Physics: Conference Series, 909, 012-060 http://doi.org/10.1088/1742-6596/909/1/012060

Supratman, Almuhdar., M.H.I., \& Ibrohim (2013). Pembelajaran Berbasis Proyek Berbantuan Media DVD 6M Untuk Memberdayakan Berpikir Kritis, Pengetahuan, dan Sikap siswa Dalam Pengelolaan Lingkungan [Project Based Learning assisted with DVD 6M Media to Empower Students' Critical Thinking Skills, Knowledge, and Attitude toward Environment Management]. Jurnal Pendidikan Biologi Universitas Negeri Malang, 5(1), 25-33.

Taale, K. D. (2013). Remediating some learning difficulties of L200 science education students of Modibbo Adama University of Technology in some physics concepts using multiple representations. International Journal of Education and Practice, 1(3), 26-43.

Tran, V. D. (2013). Effects of Student Teams Achievement Division (STAD) on Academic Achievement and Attitudes of Grade 9th Secondary School Students towards Mathematics. International Journal of Sciences, 2, 2-11.

Treffinger, D. J., Young, G. C., Selby, E. C., \& Shepardson, C. (2002). Assessing creativity: A guide for educator. Center for creative learning. Florida: Sarasota.

Tressoldi, P. E., Giofre D., Sella F., \& Cumming, G. (2013). High impact = high statistical standards? Not necessarily so. PLoS One 8, e56180.

Unglar, K. (2018). The effect of Problem Based Learning on the Creative Thinking and Critical Thinking Disposition of Students in Visual Arts. Interdisciplinary Journal of Problem-Based Learning, 12(1), 3-6 Retrieved from doi.org/10.7771/1541-5015.1649.

Vieira, R. M., \& Vieira, C. T. (2016). Fostering scientific literacy and critical thinking in elementary science education. International Journal of Science and Mathematics Education 14, 659-680. http://dx.doi.org/10.1007/s10763-014-9605-2.

Wang, X., \& Zheng H. (2016). Reasoning Critical Thinking: Is it Born or Made? Theory and Practice in Language Studies, 6(6), 1323. https://doi.org/10.17507/tpls.0606.25

Wheeler, S., Waite, S.J., \& Bromfield, C.(2002). Promoting creative thinking through the use of ICT. Journal of Computer Assisted Learning, 18, 367-378. 
Wulandari, T.S.H., Amin, M., Zubaidah, S., \& Almuhdar, M.H.I (2017). Students' Critical Thinking Improvement through PDEODE and STAD Combination in The Nutrition and Health Lecture. International Journal of Evaluation and Research in Education (IJERE), 6(2), 110-117.

Wyk, M. V, 2013 The Effect of Student Teams Achievement Divisions as a Teaching Strategy on Grade 10 Learners' Economics Knowledge. International Journal for CrossDisciplinary Subjects in Education (IJCDSE), 4(2), 1153-1155.

Yasin R.M, Mustapha R, 2008 Promoting Creativity Through Problem Oriented Project Based Learning in Engeneering Education at Malaysian Polytechnics: Issues and Challeges. Proceedings of the $8^{\text {th }}$ WSEAS International Conference on Education and Educational Technology. 253-258.

Yasin, R. M., Rahman, S, (2011) Problem Oriented Project Based Learning (POPBL) in Promoting Education for Sustainable Development. Procedia Social and Behavioral Sciences, 15, 289-293.

Yusnaeni, A. D., Corebima, Susilo, H., \& Zubaidah, S. (2017). Creative Thinking of Low Academic Student Undergoing Search Solve Create and Share Learning Integrated with Metacognitive Strategy". International Journal of Instruction, 10(2), 245-262.

Zubaidah S, Yulianti L, and Mahanal S, 2013 Model dan Metode Pembelajaran SMP IPA. Universitas Negeri Malang. ISBN: 979. 495. 602.3 pp: 1-199.

Zubaidah, S., Corebima, A. D., Mahanal, S., \& Mistianah. (2018). Revealing the Relationship between Reading Interest and Critical Thinking Skills through Remap GI and Remap Jigsaw. International Journal of Instruction, 11(2), 41-56. 